\title{
UPAYA PENINGKATAN PEMAHAMAN KONSEP FISIKA SISWA MELALUI PENERAPAN MODEL PEMBELAJARAN SQ3R (SURVEY, QUESTION, READ, RECITE \& REVIEW)
}

\author{
HIMSAR SIREGAR, H. USMAN SIREGAR, \& \\ ISKANDAR SAFRI HASIBUAN
}

Dosen Fisika UMTS

himsarsir@gmail.com

\begin{abstract}
This study departs from the problem of non-contestual learning material and low students' performance, most teachers still carry out learning in a monotonous method. Based on the problems this research this research conducted, with the aim of increasing the understanding of students' physics concepts and teacher activities in physics learning using the SQ3R learning model. This research was conducted at SMA N 1 Siabu through classroom action research with two cycles. In the first cycle, some students and teachers were not familiar with the learning conditions of the SQ3R model. In the second cycle, students and teachers have begun to understand the implementation of SQ3R learning, and have shown satisfactory results. It can be seen from the results of observations of teachers and students getting used to putting the learning atmosphere that leads to the SQ3R learning approach. From the test results, it is known that the understanding of students' physics concepts increased from 55.62 to 73.75 ; an average score is 64.66 which can be categorized as good. Mastery of learning improved from $25 \%$ in the first cycle to $67.5 \%$ in the second cycle. From the result above, it concluded that SQ3R learning can improve the understanding of students' physics concepts in physics learning in class X SMA N 1 Siabu in the academic year 2010-2011.

Keywords: Understanding of Physics Concepts, Learning Models, SQ3R, Quantities and Units
\end{abstract}

\begin{abstract}
Abstrak
Penelitian ini berangkat dari permasalahan tentang materi pembelajaran tidak kontesktual dan kinerja siswa rendah, sebagian besar guru masih melaksanakan pembelajaran dengan metode yang monoton. Berdasarkan permasalahan tersebut penelitian ini dilakukan, dengan tujuan dapat meningkatkan pemahaman konsep fisika siswa dan aktivitas guru dalam pembelajaran fisika dengan menggunakan model pembelajaran SQ3R. Penelitian ini dilakukan di SMA N 1 Siabu melalui penelitian tindakan kelas dengan dua siklus. Pada siklus pertama sebagian siswa maupun guru belum terbiasa dengan kondisi belajar model SQ3R. Dalam siklus kedua siswa dan guru sudah mulai memahami implementasi pembelajaran SQ3R, dan menunjukkan hasil yang cukup memuaskan. Hal ini dapat dilihat dari hasil observasi terhadap guru dan siswa mulai terbiasa menempatkan suasana pembelajaran yang mengarah pada pendekatan pembelajaran SQ3R. Dari hasil tes diketahui bahwa pemahaman konsep fisika siswa meningkat dari nilai 55,62
\end{abstract}


276 | TAZKIR: Jurnal Penelitian Ilmu-ilmu Sosial dan Keislaman

Vol. 03 No. 2 Desember 2017

menjadi 73,75 . Dengan rata-rata 64,66 yang dapat dikategorikan baik. Penguasaan belajar sebelumnya $25 \%$ pada siklus pertama, dan $67,5 \%$ pada siklus kedua. Dari hasil penelitian ini dapat disimpulkan bahwa pembelajaran SQ3R dapat meningkatkan pemahaman konsep fisika siswa dalam pembelajaran fisika dikelas X SMA N 1 Siabu Tahun pelajaran 2010-2011.

Kata Kunci : Pemahaman Konsep Fisika, Model Pembelajaran, SQ3R, Besaran Dan Satuan

\section{PENDAHULUAN}

Dunia pendidikan selalu menjadi topik pembicaraan yang menarik pada lingkungan masyarakat, baik lingkungan guru maupun orang tua terlebih lagi dikalangan pakar pendidikan, hal ini merupakan sesuatu yang wajar karena setiap orang ingin mendambakan dan menginginkan pendidikan yang terbaik bagi siswa, anak serta generasi penerus bangsa yang akan datang. Demikian pula halnya dengan pendidikan fisika. Fisika merupakan salah satu pendongkrak kemajuan IPTEK (ilmu pengetahuan dan teknologi). Untuk itulah kita perlu menguasai mata pelajaran fisika, dengan cara memperhatikan cara pembelajaran dalam proses kegiatan belajar mengajar, agar siswa itu lebih aktif dan kreaktif, dalam proses pembelajaran siswa sering terganjal oleh beberapa masalah, antara lain masalah metode guru penyampaian materi, istilah-istilah berupa lambang fisika dan konsep-konsep fisika lainnya. Selain faktor tersebut adalagi faktor yang fundamental mempengaruhi motivasi belajar siswa, sehingga untuk memahami konsep-konsep fisika tersebut menjadi tanjakan tinggi baginya. Faktor itu adalah faktor eksternal.

Faktor dari luar siswa dikenal dengan faktor eksternal diantaranya yaitu faktor lingkungan dan keluarga. Permasalahan-permasalahan lain yang biasanya dialami siswa dalam mengikuti pembelajaran meliputi: perbedaan kemampuan siswa menanggapi pelajaran, dalam pembelajaran siswa tidak ditekankan pemberian pengalaman nyata sesuai dengan kebutuhan masyarakat, siswa tidak ditekankan untuk lebih sering mempraktekkan dan mengulangi pelajarannya, didalam kegiatan pembelajaran tidak memberikan tugas kepada siswa sehingga siswa kurang memahami konsep dalam pelajaran itu, hal ini menurut pendapat guru mata pelajaran fisika Ahmad Rusdi, S,Pd. Agar permasalahan yang diteliti lebih jelas, kemudian hal apa saja yang membuat siswa kurang berhasil pada mata pelajaran fisika, ada beberapa cara penulis lakukan yaitu: mengadakan wawancara dengan bapak Ahmad Rusdi, S,Pd. Sebagai guru mata pelajaran fisika di kelas X. Penulis menyimpulkan metode yang biasa diterapkan dalam proses pembelajaran adalah metode ceramah, tanya jawab, terkadang membuat 
metode diskuisi. Namun faktor yang paling patal mempengaruhi cara belajar siswa adalah faktor kesalahan konsep. Selain wawancara penulis mengadakan tes diagnostik (tes awal) yang mengkhususkan pada pengujian penguasaan siswa terhadap pokok bahasan besaran dan satuan.

Adapun dasar ketuntasan yang penulis tetapkan adalah berdasarkan nilai yang diperoleh oleh siswa di SMA NEGERI 1 SIABU yaitu masih sangat kurang. Berdasarkan hasil tes diagnostik yang didapatkan rendahnya nilai tes siswa dikarenakan pemahaman konsep siswa masih kurang dalam pelajaran besaran dan satuan. Dari 40 orang jumlah siswa 10 orang cukup dan 30 orang dikategorikan kurang. Untuk mengatasi masalah ini penulis menawarkan suatu model pembelajaran yaitu model pembelajaran SQ3R dalam bentuk narasi, mungkin dengan model pembelajaran ini dapat memberikan kemudahan bagi siswa untuk mempelajari konsep itu dengan mudah. Rendahnya pemahaman konsep siswa dapat dilihat dari persentase tabel rata-rata belajar siswa menurut KKM mata pelajaran fisika mulai dari tahun pelajaran 2007-2008 sampai tahun pelajaran 2010-2011 yang tertera dibawah ini adalah sebagai berikut :

TABEL I

DAFTAR PENETAPAN KKM PER TAHUN

\begin{tabular}{|l|c|c|c|c|c|}
\hline \multirow{2}{*}{ No } & \multirow{2}{*}{ Tahun pelajaran } & \multicolumn{2}{|c|}{ Nilai siswa } & \multirow{2}{*}{ Rata-rata } & \multirow{2}{*}{ KKM } \\
\cline { 3 - 4 } & Terendah & Tertinggi & & \\
\hline 1 & $2007-2008$ & 50,00 & 70,00 & 60,00 & 60,50 \\
\hline 2 & $2008-2009$ & 50,00 & 70,20 & 60,30 & 60,75 \\
\hline 3 & $2009-2010$ & 50,25 & 70,30 & 60,40 & 70,00 \\
\hline 4 & $2010-2011$ & 50,25 & 70,30 & 60,40 & 70,00 \\
\hline
\end{tabular}

Dalam pemilihan model mengajar yang digunakan oleh guru tentunya mempengaruhi pemahaman konsep siswa. Pada prinsipnya tidak satupun model mengajar yang dipandang sempurna dan cocok untuk semua pokok bahasan, setiap model mempunyai kelebihan dan kekurangan karena itu seorang pendidik pandai memilih model yang tepat sesuai dengan tujuan yang dicapai. Kesulitan yang dialami sebahagian besar siswa dengan indikasi rendahnya nilai yang diperoleh, mungkin disebabkan pengajaran yang bersipat komfetitif induvidualistik yang membuat menurunnya motivasi belajar siswa, terutama pada siswa yang berkemampuan rendah, sehingga rasa percaya diri dan sikapnya kurang positif terhadap mata pelajaran fisika, suasana ini kurang 
278 | TAZKIR: Jurnal Penelitian Ilmu-ilmu Sosial dan Keislaman

Vol. 03 No. 2 Desember 2017

kondusif selama proses pembelajaran berlangsung dikarenakan jalinan interaksi guru dan siswa yang monoton, dan diantara siswa nyaris tidak pernah dilibatkan selama proses pembelajaran berlangsung.

Proses pembelajaran yang dicari pemecahannya dalam penelitian ini terkait pada mata pelajaran fisika, sebagai salah satu mata pelajaran yang kompleks menuntut adanya kemampuan kognitif, afektif dan psikomotorik siswa, sehingga perlu adanya strategi dan model pembelajaran SQ3R pada pokok bahasan besaran dan satuan yang mampu memberikan solusi terhadap keberhasilan pemahaman konsep fisika siswa. Adapun tujuan penelitian ini adalah untuk mengetahui tingkat pemahaman konsep fisika siswa kelas X SMA Negeri 1 Siabu pada Pokok bahasan besaran dan satuan dengan penerapan model pembelajaran SQ3R.

\section{KERANGKA TEORITIS}

\section{Hakikat belajar dan pembelajaran}

Dalam dunia pendidikan belajar bukanlah hal yang asing lagi. Belajar sudah dikenal secara meluas diberbagai kalangan. Pengertian belajar yang cukup baik diberikan oleh Djamarah, S.B dan Z.A ${ }^{1}$ yang menyatakan bahwa belajar merupakan "Proses perubahan perilaku berkat pengalaman dan latihan artinya tujuan kegiatan belajar adalah perubahan tingkah laku, baik yang menyangkut Pengetahuan, ketrampilan maupun sikap bahkan meliputi segenap aspek organisme atau pribadi". Menurut Slameto belajar adalah "suatu proses usaha yang dilakukan untuk memperoleh suatu perubahan tingkah laku yang baru secara keseluruhan sebagai hasil pengalamannya sendiri dalam interaksi dengan lingkungannya" ${ }^{\prime 2}$.

Di dalam kegiatan belajar mengajar, anak adalah sebagai subjek dan sebagai objek dari kegiatan pembelajaran dan sesuai kutipan kita di atas sangat tepatlah anak didik itu sebagai subjek dan objek pembelajaran dan pendidik hanya sebagai fasilitator. ${ }^{3}$ Karena itu, inti proses pengajaran adalah kegiatan belajar anak didik, tujuan pengajaran tentu saja akan tercapai jika anak didik

1 Syaiful Bahri Djamarah and Aswan Zain, "Strategi Belajar Mengajar," Jakarta:Rineka Cipta, 2010, 2010, https://doi.org/http://dx.doi.org/10.1016/S0278-6125(98)80001-0.

2 Slameto, Belajar Dan Faktor-Faktor Yang Mempengaruhinya (Jakarta: Rineka Cipta, 2013), hal. 2, https://search.mysearch.com/web?apn_uid=281A0B2C-51C9-43E7-8BA9ED7C16DF675C\&b=ttb\&doi=2019-06-02\&gct=tab\&guid=281A0B2C-51C9-43E7-8BA9ED7C16DF675C\&n=785869f0\&p2=\%5ECTP\%5Eprs001\%5EB2BMS\%5Eid\&si=0hca34ee000021077301 351B6145CB07EBF930FF6B57BA41870954a------.

${ }^{3}$ Djamarah and Zain, "Strategi Belajar Mengajar." 
berusaha secara aktif mencapainya. Keaktifan anak didik disini tidak hanya dituntut dari segi fisik, tetapi juga dari segi kejiwaan. Bila hanya fisik anak yang aktif, tetapi Pikiran dan mentalnya kurang aktif, maka kemungkinan besar tujuan pembelajaran tidak tercapai. Ini Sama halnya anak didik tidak belajar, karena anak didik tidak merasakan perubahan didalam dirinya. Padahal belajar pada hakikatnya adalah perubahan yang terjadi di dalam diri seseorang setelah anak itu memperoleh pembelajaran dari pendidik tersebut sewaktu terjadinya proses pembelajaran.

Metode merupakan unsur yang sangat fundamental dalam menyelenggarakan setiap jenis dan jenjang pendidikan, ini berarti bahwa berhasilnya atau tidaknya pencapaian tujuan pendidikan amat bergantung pada proses belajar yang dialami siswa. Demikian selanjutnya Slameto mengemukakan metode adalah "cara atau jalan yang harus dilalui untuk mencapai suatu tujuan tersebut ${ }^{4 \prime}$. Oleh karena tidak ada metode mengajar yang baik dalam penyampaian materi pelajaran, maka guru harus menggunakan berbagai macam metode yang memadai.

Dari berbagai uraian tentang definisi belajar diatas dapat disimpulkan bahwa belajar adalah usaha yang dilakukan oleh seseorang untuk memperoleh pengetahuan sehingga terjadi perubahan Tingkah laku sebagai hasil belajar

\section{Pemahaman konsep}

Pemahaman terhadap sebuah konsep diperlukan dalam pembelajaran. Pemahaman adalah kemampuan seseorang untuk mengerti atau memahami sesuatu ${ }^{5}$. Dengan kata lain, memahami adalah mengetahui tentang sesuatu dan dapat melihatnya dalam berbagai segi. Seseorang dikatakan memahami suatu hal apabila ia dapat memberikan penjelasan dan meniru hal tersebut dengan menggunakan kata-katanya sendiri. Pemahaman terhadap konsep dan struktur suatu materi menjadikan materi itu dipahami secara lebih komprehensif lain dari itu peserta didik lebih mudah mengingat materi itu apabila yang dipelajari merupakan pola yang berstruktur. Dengan memahami konsep dan struktur akan mempermudah terjadinya transfer. Pemahaman konsep yaitu memahami sesuatu kemampuan mengerti, mengubah informasi ke dalam bentuk yang bermakna ${ }^{6}$.

\footnotetext{
${ }^{4}$ Slameto, Belajar Dan Faktor-Faktor Yang Mempengaruhinya, hal. 82.

${ }^{5}$ Tanpa Nama, "PENGERTIAN PEMAHAMAN KONSEP," Berbagi Ilmu, 2016, https://www.rijal09.com/2016/04/pengertian-pemahaman-konsep.html.

6 Rike Marjulisa, "Pemahaman Konsep," Scribd, 2011, https://id.scribd.com/doc/67839324/Pemahaman-Konsep.
} 
280 | TAZKIR: Jurnal Penelitian Ilmu-ilmu Sosial dan Keislaman

Vol. 03 No. 2 Desember 2017

Berdasarkan pengertian di atas kita dapat disimpulkan bahwa pemahaman konsep adalah perbuatan memahami gambaran mental dari suatu objek dari suatu peristiwa. Dengan kata lain pemahaman konsep yaitu memahami sesuatu kemampuan mengerti, mengubah informasi ke dalam bentuk yang bermakna. Suatu konsep akan menjadi dasar bagi proses-proses perkembangan mental yang lebih tinggi untuk merumuskan prinsip-prinsip dan generalisasi-generalisas dalam pemecahan suatu masalah, siswa dituntut mengetahui aturan-aturan yang relevan.

Adapun langkah menanamkan sebuah konsep menurut teori belajar Bruner adalah sebagai berikut?: 1) pengajar memberikan contoh yang berhubungan dengan konsep sesuai dengan struktur kognitif siswa, 2) peserta didik diberi dua atau tiga contoh dengan bentuk pertanyaan, 3) peserta didik diminta memberikan contoh sendiri suatu konsep tentang suatu konsep untuk mengetahui apakah mereka sudah memahami konsep tersebut, 4) peserta didik diminta mencoba mendefenisikan konsep tersebut dengan bahasanya sendiri, dan 5) peserta didik diberikan lagi contoh mengenai konsep dan bukan konsep.

Siswa dikatakan paham terhadap suatu konsep apabila ia telah dapat memenuhi indikator-indikator yang telah ditetapkan. Adapun indikator bahwa mahasiswa telah memahami konsep dinyatakan dalam Peraturan Pemerintah No. 56 tahun $24^{8}$ sebagai berikut:

1. menyatakan ulang sebuah konsep;

2. mengklasifikasikan objek menurut tertentu sesuai dengan konsepnya;

3. memberikan contoh dan bukan contoh dari suatu konsep;

4. menyajikan konsep dalam berbagai bentuk representasi;

5. mengembangkan syarat perlu atau syarat cukup dari suatu konsep;

6. menggunakan dan memanfaatkan serta memilih prosedur atau operasi tertentu;

7. mengaplikasikan konsep atau algoritma dalam pemecahan masalah. Jadi dapat difahami bahwa seseorang yang sudah memiliki pemahaman konsep adalah sesorang yang memahami konsep yang diberikan, memaknainya, dan mengaplikasikannya dalam pembelajaran yang dihadapinya.

\footnotetext{
${ }^{7}$ Rike Marjulisa.

8 Ditektorat Jenderal Dikdasmen, "Peraturan Dirjen Dikdasmen Nomor 506/C/Kep/PP/2004," Depdiknas, 2004, https://search.mysearch.com/web?apn_uid=281A0B2C51C9-43E7-8BA9-ED7C16DF675C\&b=ttb\&doi=2019-06-02\&gct=tab\&guid=281A0B2C-51C9-43E78BA9ED7C16DF675C\&n=785869f0\&p2=\%5ECTP\%5Eprs001\%5EB2BMS\%5Eid\&page=1\&q=Peraturan+Dir jen+Dikdasmen+Nomor+506\%2FC\%2FKep $\% 2$ FPP $\% 2 F 2$.
} 


\section{Model Pembelajaran SQ3R}

Model pembelajaran SQ3R adalah singkatan dari Survey, Question, Read, Recite, Review'. SQ3R ini merupakan strategi memahami untuk membantu siswa untuk mempelajari pelajaran berikutnya. ${ }^{10}$ Dengan demikian diharapkan strategi ini bisa membantu pemebaljaran siswa untuk memahami pembelajaran mereka. Terkait dengan SQ3R yang terdiri dari 5 (lima) singkatan, maka uraian dari sinkatan tersebut adalah sebagai berikut. Survei yaitu siswa memeriksa atau meneliti atau mengidentifikasi seluruh teks. Kedua, question yaitu siswa menyusun daftar pertanyaan yang relevan dengan teks. Ketiga, read yaitu siswa Membaca teks secara aktif dan mencari jawaban atas pertanyaan-pertanyaan yang telah disusun. Keempat, recite yakni siswa menghapal setiap jawaban yang telah ditemukan. Kelima, review yaitu siswa meninjau ulang seluruh jawaban atas pertanyaan yang telah tersusun pada langkah kedua dan ketiga.

Waktu yang digunakan untuk mempelajari atau memahami sebuah teks dengan Model pembelajaran SQ3R tidak banyak berbeda dengan menggunakan model pembelajaran yang lain. Oleh karena itu peneliti yakin bahwa strategi ini bisa digunakan untuk memahami konsep-konsep dalam pembelajaran Biologi, Fisika, dan lain sebagainya.

\section{Besaran Pokok dan Besaran Turunan}

Besaran adalah segala sesuatu yang mempunyai nilai, yang dapat dinyatakan dalam angka, sedangkan satuan adalah tanda atau simbol untuk menyatakan besaran tersebut. Besaran merupakan sesuatu yang dapat di ukur dan dinyatakan dalam sebuah nilai dengan satuan-satuan yang telah ditetapkan dan satuan adalah tanda atau simbol yang digunakan untuk besaran ${ }^{11}$. Kedua satuan ini adalah satuan yang digunakan dalam fisika.

Besaran dapat kita bagi menjadi dua, yakni besaran pokok dan besaran turunan. Besaran pokok adalah besaran yang dapat berdiri sendiri tanpa menurunkannya dari Besaran-besaran lainnya, maksudnya besaran yang satuannya telah ditetapkan sesuai dengan System Internasional (SI). Besaran

9 No Name, "The SQ3R Reading Method," Study Guides and Strategies, 2017, https://www.studygs.net/texred2.htm.

10 No Name, “SQ3R: Survey-Question-Read-Recite-Review," Adolescent Literacy, 2017, http://www.adlit.org/strategies/19803/.

11 Studio Belajar, "Besaran Pokok Dan Besaran Turunan - Pengertian, Contoh, \&amp; Dimensi," Studi Belajar, 2015, https://www.studiobelajar.com/besaran-pokok-dan-besaranturunan/. 
282 | TAZKIR: Jurnal Penelitian Ilmu-ilmu Sosial dan Keislaman

Vol. 03 No. 2 Desember 2017

pokok hanya terdiri dari 7 besaran, yakni panjang, massa, waktu, kuat arus listrik, suhu, jumlah zat, dan intensitas cahaya.

Besaran turunan adalah besaran yang dapat diturunkan dari besaran pokok. Dimana besaran turunan itu juga memiliki satuan, dan dimensi. Dimana satuan dan dimensinya sudah memiliki ketetapan sesuai dengan system Internasional. Besaran turunan contohnya adalah volume, kecepatan, massa jenis, usaha, energy, dan lain lain.

\section{METODE PENELITIAN}

Penelitian ini dilakukan dengan metode penelitian tidakan kelas, dengan dua siklus yang didalamnya terdapat 4 (empat) proses, yakni perencanaan, pelaksanaan, observasi, dan refleksi. Subjek penelitian adalah siswa kelas $\mathrm{X}^{1}$ SMA Negeri 1 Siabu yang terdiri dari 40 siswa dengan komposisi laki-laki 14 dan perempuan 26 orang siswa. Alat pengumpulan data dalam penelitian ini adalah test, observasi dan angket. Data dianalisis secara kualitatif dan kuantitatif.

\section{HASIL PENELITIAN DAN PEMBAHASAN}

\section{Deskripsi Data Dan Hasil Penelitian}

Berdasarkan pengamatan terhadap jalannya proses pembelajaran fisika di SMA Negeri 1 Siabu selama ini, dilakukan dengan menginventarisasi problem pembelajaran fisika yang berhubungan dengan penerapan model pembelajaran SQ3R dan peningkatan pemahaman konsep fisika siswa. Sebelum data-data yang terkumpul dianalisa terlebih dahulu, data diperiksa, baik data yang berupa angket, lembar observasi, maupun data berupa nilai siswa yang diperoleh dari hasil tes yang di berikan.

Untuk melihat bagaimana keadaan nilai siswa sebelum penerapan model pembelajaran SQ3R maka diadakanlah pretest di kelas $\mathrm{X}^{1}$ pada pokok bahasan besaran dan satuan maka didapatlah hasil belajar siswa dalam distribusi frekuensi nilai pemahaman konsep fisika siswa pretest

\begin{tabular}{|c|c|c|c|}
\hline No & Rentang nilai & Frekuensi siswa & Predikat \\
\hline 1 & $00-25$ & - & Kurang \\
\hline 2 & $26-50$ & 18 & Cukup \\
\hline 3 & $51-75$ & 22 & Baik \\
\hline 4 & $76-100$ & - & Sangat baik \\
\hline \multicolumn{2}{|r|}{ Jumlah } & 40 Siswa \\
\hline
\end{tabular}


Sementara itu jika kita bandingkan dengan KKM yang ditetapkan oleh SMA Negeri 1 Siabu yaitu 70 maka siswa yang lulus atau dikatakan tuntas hanyalah $25 \%$ untuk lebih jelasnya dapat dilihat pada tabel dibawah ini :

TABEL VII

KEADAAN NILAI SISWA SEBELUM PENERAPAN SQ3R.

\begin{tabular}{|c|c|c|c|}
\hline No & Nilai & Jumlah siswa & Keterangan \\
\hline 1 & $<69$ & 30 & Tidak tuntas \\
\hline 2 & $>70$ & 10 & Tuntas \\
\hline \multicolumn{2}{|c|}{ Jumlah } & 40 Siswa \\
\hline
\end{tabular}

Berdasarkan hasil test pemahaman konsep fisika siswa di atas maka peneliti mencoba memperbaiki nilai hasil belajar siswa SMA Negeri 1 Siabu kelas $\mathrm{X}^{1}$ pada pokok bahasan besaran dan satuan tahun pelajaran 2010-2011 dengan menggunakan penerapan model pembelajaran SQ3R.

\section{Siklus I}

Untuk memperbaiki pemahaman konsep fisika siswa maka peneliti memulainya dengan melakukan dan menerapkan model pembelajaran SQ3R pada siklus I ini. Pada pelaksanaan siklus I peneliti membaginya dalam 4 tahap, yakni perencanaan (planning), pelaksanaan (acting), pengamatan (observing) dan refleksi (reflection) seperti berikut:

a. Perencanaan (planning)

Perencanaan pada siklus ini berdasarkan dengan beberapa langkah, antara lain :

1) Memberikan motivasi kepada siswa agar lebih aktif lagi dalam mengikuti proses pembelajaran.

2) Lebih intensif membimbing siswa yang masih mengalami kesulitan dalam mengikuti proses pembelajaran.

3) Memberikan pengakuan atau penghargaan

4) Membuat perbaikan terhadap rencana pelaksanaan pembelajaran dengan memnggunakan model penerapan pokok pembelajaran SQ3R yang lebih mudah dipahami siswa serta dengan terus memotivasi siswa untuk aktif dalam memberikan pertanyaan jika masih ada pelajaran yang belum dapat atau masih kurang dipahami.

b. Pelaksanaan (acting) 
284 | TAZKIR: Jurnal Penelitian Ilmu-ilmu Sosial dan Keislaman

Vol. 03 No. 2 Desember 2017

1) Suasana pembelajaran sudah mulai mengarah kepada model penerapan pokok pembelajaran SQ3R, terbukti dari tugas yang diberikan guru kepada siswa sudah mulai dimengerti dan dilaksanakan siswa dengan menggunakan waktu yang cukup optimal dan efisien.

2) Sebagian besar siswa sudah merasa termotivasi untuk bertanya dan menganggapi apa yang disampaikan oleh guru.

3) Kegiatan pembelajaran yang kondusif, efektif dan menyenangkan sudah mulai tercipta.

c. Observasi dan Evaluasi (Observing and Evaluation)

1) Keadaan hasil pemahaman konsep fisika siswa pada siklus I mengalami peningkatan dari proses sebelum siklus dilakukan . Hal ini dapat dilihat dari rata-rata hasil belajar pemahaman konsep fisika siswa kelas $X^{1}$ SMA Negeri 1 Siabu yang mengalami peningkatan yang cukup signifikan. Pada siklus I ini diperoleh rata-rata hasil pemahaman konsep fisika siswa adalah 68,00 dan sekitar 67,5\% siswa yang memperoleh nilai tuntas atau yang nialainya diatas KKM. Berdasarkan hasil tersebut maka pembelajaran dikatakan berhasil.

Data mahasiswa dari hasil siklus pertama adalah:

Tabel VIII

Distribusi frekuensi pemahaman konsep fisika Siswa Pada Siklus I

\begin{tabular}{|c|c|c|c|}
\hline No & Rentang nilai & Frekuensi siswa & Predikat \\
\hline 1 & $00-25$ & - & Kurang \\
\hline 2 & $26-50$ & - & Cukup \\
\hline 3 & $51-75$ & 30 & Baik \\
\hline 4 & $76-100$ & 10 & Sangat baik \\
\hline \multicolumn{2}{|c|}{ Jumlah } & $40 \quad$ Siswa \\
\hline
\end{tabular}

Jika kita bandingkan dengan KKM yang ditetapkan oleh SMA Negeri 1 Siabu yaitu 70 maka siswa yang lulus atau dikatakan tuntas hanyalah 67,5\%. Untuk lebih jelasnya dapat dilihat pada tabel dibawah ini:

Tabel IX

Keadaan Nilai Siswa Pada Siklus I

\begin{tabular}{|c|c|c|c|}
\hline No & Nilai & Jumlah siswa & Keterangan \\
\hline 1 & $<69$ & 13 & Belum tuntas \\
\hline
\end{tabular}




\begin{tabular}{|c|c|cc|c|}
\hline 2 & $>70$ & 27 & Tuntas \\
\hline \multicolumn{2}{|c|}{ Jumlah } & \multicolumn{2}{|c|}{ Siswa } \\
\hline
\end{tabular}

2) Hasil observasi aktivitas guru dalam proses belajar mengajar pada siklus I ini tergolong agak baik. Hal ini berarti mengalami peningkatan dari proses sebelum siklus, dimana persentasi kelulusan atau ketuntasan hasil pemahaman konsep fisika siswa mengalami peningkatan yang cukup berarti dan partisipasi siswa dalam kegiatan proses pembelajaran. Mereka sudah mulai memahami dan mengetahui prinsip kerja model penerapan pokok pembelajaran SQ3R.

3) Hasil evaluasi penguasaan siswa terhadap materi yang diberikan guru pada siklus I ini sudah tergolong agak bagus, hal ini terbukti dari hasil pemahaman konsep fisika siswa yang dulunya hanya 10 siswa yang memperoleh nilai ketuntasan atau sekitar $25 \%$ sekarang meningkat, siswa yang memperoleh nilai tuntas sudah mencapai 27 siswa atau sekitar $67,5 \%$.

4) Partisipasi siswa pada siklus I ini sudah mulai meningkat. Terbukti dari semakin banyaknya siswa yang bertanya dan kondisi situasi belajar mengajar kelas semakin hidup dan kondusif.

d. Refleksi dan prencanaaan ulang (Reflection and Replaning)

Adapun keberhasilan yang diperoleh selama siklus I berlangsung adalah sebagai berikut:

1) Partisipasi dan kreativitas siswa dalam proses belajar mengajar sudah mengarah kepada model penerapan pokok pembelajaran SQ3R. Siswa mulai antusias balam belajar dan sudah mulai paham dan memahami tugas yang diberikan oleh guru, Siswa juga sudah mulai mampu menggunakan efisiensi waktu dengan cukup optimal, Siswa mulai mampu mempresentasikan model penerapan pokok pembelajaran SQ3R dalam mempelajari pokok bahasan besaran dan satuan. Hal ini dapat terlihat dari data hasil observasi siswa terhadap aktivitas kreatif siswa meningkat dari 55,62 pada siklus I menjadi 64,62 pada siklus I.

2) Meningkatnya kreativitas siswa dalam proses belajar mengajar didukung oleh meningkatnya kreativitas guru dalam mempertahankan dan meningkatkan suasana pembelajaran yang mengarah kepada model penerapan pokok pembelajaran SQ3R. Guru 
286 | TAZKIR: Jurnal Penelitian Ilmu-ilmu Sosial dan Keislaman

Vol. 03 No. 2 Desember 2017

secara intensif membimbing siswa saat siswa mengalami kesulitan dalam proses belajar mengajar dapat dilihat dari observasi aktivitas guru dalam proses belajar mengajar meningkat dari 55,62 pada sebelum siklus menjadi 64,62 pada siklus I.

3) Meningkatnya kreativitas siswa dalam melaksanakan evaluasi terhadap kemampuan siswa menguasai materi pembelajaran dari hasil belajar fisika siswa yang dulunya hanya 10 siswa yang memperoleh nilai ketuntasan atau sekitar $25 \%$ sekarang meningkat, siswa yang memperoleh nilai tuntas sudah mencapai 27 siswa atau sekitar $67,5 \%$.

Berdasarkan hasil observasi yang dilakukan peneliti pada siklus I dapat kita simpulkan bahwa:

1) Peningkatan pemahaman konsep fisika siswa mengalami peningkatan yang cukup baik dari yang dahulunya siswa yang memperoleh nilai tuntas hanya 10 orang atau sekitar $25 \%$ pada sebelum siklus I menjadi $67,5 \%$ pada siklus yang I.

2) Siswa semakin antusias dalam mengikuti proses belajar mengajar.

3) Partisipasi siswa juga mengalami peningkatan, hal ini dapat terlihat dari semakin banyaknya siswa yang tidak segan-segan lagi untuk bertanya tentang apa yang belum diketahui atau pahaminya.

4) Pemanfaatan waktu juga sudah mulai membaik dan siswa pun sudah semakin sadar akan tugas dan tanggung jawab yang diberikan oleh guru.

Berdasarkan hasil pemahaman konsep fisika siswa diatas, siswa yang memperoleh nilai tuntas belum mencapai $75 \%$, sehingga peneliti masih harus melanjutkan penelitian pada siklus II.

\section{Siklus II}

Pada siklus II peneliti tetap melakukan perbaikan tehnik, media yang lebih efektif dan koleksi materi yang akan diajarkan kepada siswa dengan memperhatikan kelemahan-kelemahan yang didapatkan pada siklus I, namun demikian peneliti tetap konsisten terhadap konsep awal yaitu dengan menggunakan model penerapan pokok pembelajaran SQ3R dan masih pada pokok bahasan besaran dan satuan.

a. Perencanaan (planning)

Perencanaan pada siklus ini berdasarkan perencanaan pada siklus

I dengan beberapa perbaikan, antara lain : 
1) Mengadakan wawancara dengan siswa yang masih mengalami kesulitan dalam menerapkan model penerapan pokok pembelajaran SQ3R sekaligus membicarakan solusi-solusi yang harus dilakukan demi perbaikan dalam proses belajar mengajar selanjutnya

2) Memberikan motivasi kepada siswa agar lebih aktif lagi dalam mengikuti proses pembelajaran.

3) Lebih intensif membimbing siswa yang masih mengalami kesulitan dalam mengikuti proses pembelajaran.

4) Memberikan pengakuan atau penghargaan kepada siswa yang sudah sudah dapat memahami model penerapan pokok pembelajaran SQ3R dengan melihat pemahaman konsep fisika siswa pada siklus sebelumnya.

5) Membuat perangkat pembelajaran dengan memnggunakan model penerapan pokok pembelajaran SQ3R yang lebih mudah dipahami siswa serta dengan terus memotivasi siswa untuk aktif dalam memberikan pertanyaan jika masih ada pelajaran yang belum dapat atau masih kurang dipahami.

b. Pelaksanaan (acting)

1) Siswa sudah sangat antusias dalam mengikuti kegiatan proses belajar mengajar karena berdasarkan dari hasil wawancara peneliti dengan beberapa siswa yang dipilih secara acak. Mereka menyebutkan bahwa belajar dengan menggunakan model penerapan pokok pembelajaran SQ3R tidak memberati beban pikiran mereka. Belajar dengan menggunakan model penerapan pokok pembelajaran SQ3R sama artinya dengan belajar dengan santai namun pasti.

2) Suasana pembelajaran sudah mulai mengarah kepada model penerapan pokok pembelajaran SQ3R, terbukti dari tugas yang diberikan guru kepada siswa sudah mulai dimengerti dan dilaksanakan siswa dengan menggunakan waktu yang cukup optimal dan efisien.

3) Sebagian besar siswa sudah merasa termotivasi untuk bertanya dan menganggapi apa yang disampaikan oleh guru.

4) Kegiatan pembelajaran yang kondusif, efektif dan menyenangkan sudah mulai tercipta. 
288 | TAZKIR: Jurnal Penelitian Ilmu-ilmu Sosial dan Keislaman

Vol. 03 No. 2 Desember 2017

5) Situasi kelas semakin hidup dan siswa pun merasa senang dan nyaman dalam mengikuti proses belajar mengajar.

6) Pemanfaatan waktu sudah mulai terkontrol dengan baik dan sikap siswa juga dalam proses belajar mengajar mulai bertambah baik.

7) Diakhir pada pertemuan II siswa diberikan angket yang fungsinya untuk mengukur minat siswa dalam mengikuti proses pembelajaran dengan membandingkan antara menggunakan model penerapan pokok pembelajaran SQ3R dan sebelum menggunakan model penerapan pokok pembelajaran SQ3R.

8) Jika dilihat dari antusias siswa dalam mengikuti proses pembelajaran pada siklus II ini maka peneliti merasa heran karena peningkatan partisipasi siswa dalam mengikuti proses pembelajaran sangat besar hal ini terlihat dari guru merasa kewalahan dalam menjawab pertanyaan-pertanyaan yang dilemparkan oleh para siswa.

9) Selain hasil belajar siswa dan aktivitas siswa yang meningkat pada siklus II ini kreativitas siswa juga mengalami peningkatan, hal ini dapat terlihat dari cara penyusunan daftar pertanyan yang diajukan oleh siswa yang tadinya pentanyaannya sangat tidak logis dan tidak berbobot sekarang sudah mulai mengarah pada pertanyaan yang logis dan berbobot.

c. Observasi dan Evaluasi (Observing and Evaluation)

1) Keadaan hasil pemahaman konsep fisika siswa pada siklus II mengalami peningkatan dari siklus I. Hal ini dapat dilihat dari rata-rata pemahaman konsep fisika siswa kelas $X^{1}$ SMA Negeri 1 Siabu yang mengalami peningkatan yang cukup signifikan. Pada siklus II ini diperoleh rata-rata pemahaman konsep fisika siswa adalah 76,50 dan semua siswa memperoleh nilai tuntas yang artinya nilai seluruh siswa kelas X³ SMA Negeri 1 Siabu diatas KKM dan sekitar 100 \% siswa yang memperoleh nilai tuntas atau yang nilainya diatas KKM. Berdasarkan hasil tersebut maka pembelajaran dikatakan berhasil. Untuk lebih jelas berikut ini disajikan data hasil pengamatan pada siklus II.

Distribusi frekuensi pemahaman konsep fisika Siswa Pada Siklus II

\begin{tabular}{|c|c|c|c|}
\hline No & Rentang nilai & Frekuensi siswa & Predikat \\
\hline 1 & $00-25$ & - & Kurang \\
\hline
\end{tabular}




\begin{tabular}{|c|c|c|c|}
\hline 2 & $26-50$ & - & Cukup \\
\hline 3 & $51-75$ & 16 & Baik \\
\hline 4 & $76-100$ & 24 & Sangat baik \\
\hline \multicolumn{2}{|c|}{ Jumlah } & $40 \quad$ Siswa \\
\hline
\end{tabular}

(Suharsimi, A: 2009:295)

Jika kita bandingkan dengan KKM yang ditetapkan oleh SMA Negeri 1 Siabu yaitu 70 maka siswa yang lulus atau dikatakan tuntas adalah 40 siswa atau sudah mencapai 100\% dengan nilai rata-rata 76,50. Untuk lebih jelasnya dapat dilihat pada tabel dibawah ini:

Tabel X

Keadaan Nilai Siswa Pada Siklus II

\begin{tabular}{|c|c|c|c|}
\hline No & Nilai & Jumlah siswa & Keterangan \\
\hline 1 & $<69$ & - & Belum tuntas \\
\hline 2 & $>70$ & 40 & Tuntas \\
\hline \multicolumn{2}{|c|}{ Jumlah } & 40 Siswa \\
\hline
\end{tabular}

Selain Posttest dan Lembar Observasi siswa, peneliti juga menggunakan angket untuk mengetahui minat belajar siswa dalam mengikuti proses pembelajaran dengan menggunakan model penerapan pokok pembelajaran SQ3R. Pemberian angket hanya dilakukan pada siklus II karena fungsi dari angket disini hanya sebagai alat untuk mengukur minat siswa saja terhadap model penerapan pokok pembelajaran SQ3R dan sebelum menggunakan model penerapan pokok pembelajaran SQ3R.

Hasil angket yang diberikan dapat dilihat pada tabel berikut :

Tabel XI

Distribusi frekusensi angket Siswa

\begin{tabular}{|c|c|c|c|}
\hline No & Rentang nilai & Frekuensi siswa & Predikat \\
\hline 1 & $00-25$ & - & Kurang \\
\hline 2 & $26-50$ & - & Cukup \\
\hline 3 & $51-75$ & 28 & Baik \\
\hline 4 & $76-100$ & 12 & Sangat baik \\
\hline \multicolumn{3}{|c|}{ Jumlah } & $40 \quad$ Siswa \\
\hline
\end{tabular}

(Suharsimi,A :2009:295) 
Dari hasil angket siswa dapat dilihat bahwa mana siswa yang mempunyai minat belajar tinggi pada umumnya mendapat nilai yang tinggi dan sebaliknya.

d. Refleksi (Reflection)

berikut:

Hasil yang diperoleh selama siklus II berlangsung adalah sebagai

1) Partisipasi dan kreativitas siswa dalam proses belajar mengajar sudah mengarah kepada model penerapan pokok pembelajaran SQ3R. Siswa mulai antusias balam belajar dan sudah mulai paham dan memahami tugas yang diberikan oleh guru, Siswa juga sudah mulai mampu menggunakan efisiensi waktu dengan cukup optimal, Siswa mulai mampu mempresentasikan model penerapan pokok pembelajaran SQ3R dalam mempelajari pokok bahasan besaran dan satuan. Hal ini dapat terlihat dari data hasil observasi siswa terhadap aktivitas kreatif siswa meningkat dari 64,62 pada siklus I menjadi 73,75 pada siklus II.

2) Meningkatnya kreativitas siswa dalam proses belajar mengajar didukung oleh meningkatnya kreativitas guru dalam mempertahankan dan meningkatkan suasana pembelajaran yang mengarah kepada model penerapan pokok pembelajaran SQ3R. Guru secara intensif membimbing siswa saat siswa mengalami kesulitan dalam proses belajar mengajar dapat dilihat dari observasi aktivitas guru dalam proses belajar mengajar meningkat dari $70 \%$ pada siklus I menjadi $90 \%$ pada siklus II.

3) Meningkatnya kreativitas siswa dalam melaksanakan evaluasi terhadap kemampuan siswa menguasai materi pembelajaran dari hasil pemahaman konsep fisika siswa yang dulunya hanya 27 siswa yang memperoleh nilai ketuntasan atau sekitar $67,5 \%$ pada siklus I sekarang meningkat, siswa yang memperoleh nilai tuntas sudah mencapai 40 siswa atau sekitar $100 \%$ pada siklus II.

4) Meningkatnya rata-rata nilai ulangan harian siswa dari 50 (ulangan harian I sebelum penerapan model penerapan pokok pembelajaran SQ3R) kemudian pada siklus I nilai rata-rata hasil pemahaman konsep fisika siswa adalah menjadi 68,00 (ulangan harian ke-dua). Sedangkan rata-rata pemahaman konsep fisika siswa pada siklus II adalah 76,50 (ulangan harian ke-tiga)

Berdasarkan hasil yang diperoleh dari siklus II, maka dapat disimpulkan bahwa : 
1) Hasil pemahaman konsep fisika siswa mengalami peningkatan yang cukup signifikan dari yang dulunya hanya 27 siswa yang memperoleh nilai ketuntasan atau sekitar $67,5 \%$ pada siklus I sekarang meningkat, siswa yang memperoleh nilai tuntas sudah mencapai 40 siswa atau sekitar $100 \%$ pada siklus II.

2) Dengan meningkatnya partisipasi siswa dalam mengikuti proses belajar mengajar dapat juga menhingkatkan hasil pemahaman konsep fisika siswa.

3) Guru mempunyai semangat yang semakin tinggi dalam mengadakan proses belajar mengajar jika siswa yang diajarinya atai dididiknya mempunyai partisipasi yang tinggi pula.

4) Siswa sudah memahami cara-cara dan teknik pembelajaran yang menggunakan model penerapan pokok pembelajaran SQ3R.

5) Pemamfaatan waktu sudah mulai dimanfaatkan dengan baik oleh siswa dan dan guru.

6) Siswa sangat senang dan antusias dalam mengikuti proses belajar mengajar dengan menggunakan model penerapan pokok pembelajaran SQ3R. Hal ini dapat dilihat dari kegiatan siswa selama terjadi proses belajar mengajar di kelas.

Berdasarkan hasil yang dicapai pada siklus II ini bahwa nilai ketuntasan sudah mencapai $100 \%$. Artinya peneliti tidak perlu lagi melanjutkan ke siklus berikutnya dengan kata lain siklus dihentikan..

\section{B. Pembahasan}

1. Hasil pemahaman konsep fisika siswa dari siklus ke siklus

Untuk melihat bagaimana hasil yang dapat diperoleh dari penelitian dengan menggunakan model penerapan pokok pembelajara SQ3R yang dilakukan di SMA Negeri 1 Siabu tentang upaya peningkatan hasil belajar dari sebelum menggunakan model penerapan pokok pembelajaran SQ3R sampai pada siklus I, dan II secara umum bagaimana keadaan nilai ketuntasan siswa dihitung berdasarkan jumlah siswa dari sebelum menggunakan model penerapan pokok pembelajaran SQ3R sampai pada siklus I dan siklus II terjadi peningkatan.

Hasil penelitian ini menunjukkan bahwa SQ3R mampu meingkatkan pemahaman konsep siswa tentang besaran dan turunan. Hal 
ini juga ditunjukkan oleh Ratnasari ${ }^{12}$ yang telah membuktikan bahwa strategi ini dapat diterapkan pada pembelajaran fisikan dan menghasilkan hasil pemeblajaran yang lbeih baik dari sebelumnya.

Hal demikian juga telah dibuktikan oleh ISnaeni ${ }^{13}$ yang menunjukkan hasil pembelajaran Matematika juga lebih baik dengan menggunakan SQ3R untuk pembelajaran tersebut. Pembelajaran matematika dengan menggunakan SQ3R baik digunakan untuk siswa agar pemahaman siswa menjadi meningkat.

Hasil penelitian ini menunjukkan ada hubungan antara model penerapan pokok pembelajaran SQ3R dengan partisipasi, minat belajar dan hasil belajar kimia siswa kelas $X^{1}$ di SMA Negeri 1 Siabu pada Tahun Pelajaran 2009-2010. Dengan demikian nyatalah bahwa penerapan pokok pembelajaran SQ3R dapat meningkatkan minat belajar dan partisipasi siswa serta keberhasilan proses mengajar belajar sekaligus dapat meningkatkan hasil belajar siswa yang bersangkutan di suatu sekolah.

Dengan demikian model penerapan pokok pembelajaran SQ3R sangatlah dibutuhkan dalam peningkatan hasil belajar siswa karena denga model penerapan pokok pembelajaran SQ3R siswa akan lebih banyak aktif dan terlibat langsung dengan apa yang dipelajarinya sehingga dengan secara tidak langsung model penerapan pokok pembelajaran SQ3R dapat meningkatkan motovasi yang dimiliki siswa serta hasil belajar yang diperolehnya juga akan semakin baik dan tujuan pembelajaran yang diinginkanpun dapat tercapai.

\section{KESIMPULAN DAN SARAN-SARAN \\ Kesimpulan}

1. Hasil pemahaman konsep fisika siswa dengan menggunakan model penerapan pembelajaran SQ3R mulai dari siklus I, sampai II mengalami peningkatan, pada mulanya siswa yang memperoleh nilai tuntas hanya 10 orang siswa, Pada siklus I menjadi 27 siswa, sehingga pada siklus II menjadi 40 Siswa.

2. Aktivitas siswa dalam mengikuti proses pembelajaran dengan menggunakan model penerapan pembelajaran SQ3R semakin meningkat.

\footnotetext{
12 Y Ratnasari - Refleksi Edukatika and undefined 2011, "Penerapan Strategi SQ3R Dan Peta Konsep Dalam Pembelajaran Fisika Ditinjau Dari Kemampuan Memori Siswa," Eprints.Umk.Ac.Id, accessed June 14, 2019, http://eprints.umk.ac.id/3643/.

${ }^{13} \mathrm{~T}$ Isnaeni, "Pengaruh Model Pembelajaran Kooperatif Tipe SQ3R (Survey, Question, Read, Recite, Review) Terhadap Hasil Belajar Matematika Bagi Siswa," 2016.
} 
3. Minat belajar siswa dalam mengikuti proses pembelajaran dengan menggunakan model penerapan pembelajaran SQ3R semakin Meningkat. Hal ini dapat terlihat dari hasil responden pengisian angket yang diberikan kepada siswa. Seperti tercantum pada lampiran.

4. Model penerapan pembelajaran SQ3R dapat meningkatkan hasil pemahaman konsep fisika siswa di SMA Negeri 1 Siabu pada kelas $X^{1}$ pada pokok bahasan besaran dan satuan tahun pelajaran 2010-2011.

\section{Saran-saran}

Sehubungan dengan kesimpulan yang ditemukan dalam penulisan skripsi ini, maka penulis menganjurkan beberapa saran sebagai berikut;

1. Kepada para guru fisika supaya lebih mengaktifkan siswa dalam mengikuti proses pembelajaran di sekolah dengan melibatkannya secara langsung dalam menemukan konsep-konsep pembelajaran serta menggunakan strategi pembelajaran yang dapat mengaktifkan siswa yang salah satunya adalah dengan model penerapan pembelajaran SQ3R. Dengan mengaktifkan siswa berarti secara tidak langsung akan meningkatkan minat dan partisipasi siswa dalam mengikuti proses pembelajaran sehingga hasil belajar siswa pun akan meningkat. Dan juga terus menjaga hubungan yang baik dalam mendukung anak didik belajar disekolah dan di rumah.

2. Kepada anak didik agar terus berusaha meningkatkan hasil belajar kearah yang lebih baik.

3. Kepada kepala sekolah SMA Negeri 1 Siabu agar terus mengupayakan membina dan bekerja sama dengan para guru dan siswa dalam berbagai hal sebagai peningkatan hasil belajar siswa. 
294 | TAZKIR: Jurnal Penelitian Ilmu-ilmu Sosial dan Keislaman

Vol. 03 No. 2 Desember 2017

\section{DAFTAR PUSTAKA}

Dikdasmen, Ditektorat Jenderal. "Peraturan Dirjen Dikdasmen Nomor 506/C/Kep/PP/2004." D Depdiknas, 2004. https://search.mysearch.com/web?apn_uid=281A0B2C-51C9-43E7-8BA9ED7C16DF675C\&b=ttb\&doi=2019-06-02\&gct=tab\&guid=281A0B2C-51C943E7-8BA9-

ED7C16DF675C\&n=785869f0\&p2=\%5ECTP\%5Eprs001\%5EB2BMS\%5Eid\&pa ge $=1 \& q=$ Peraturan+Dirjen+Dikdasmen+Nomor+506\%2FC $\% 2 F K e p \% 2 F P P \% 2$ F2.

Djamarah, Syaiful Bahri, and Aswan Zain. "Strategi Belajar Mengajar." Jakarta:Rineka Cipta, 2010, 2010. https://doi.org/http://dx.doi.org/10.1016/S0278-6125(98)80001-0.

Edukatika, Y Ratnasari - Refleksi, and undefined 2011. “Penerapan Strategi SQ3R Dan Peta Konsep Dalam Pembelajaran Fisika Ditinjau Dari Kemampuan Memori Siswa." Eprints.Umk.Ac.Id. Accessed June 14, 2019. http://eprints.umk.ac.id/3643/.

Isnaeni, T. "Pengaruh Model Pembelajaran Kooperatif Tipe SQ3R (Survey, Question, Read, Recite, Review) Terhadap Hasil Belajar Matematika Bagi Siswa," 2016.

No Name. "SQ3R: Survey-Question-Read-Recite-Review.” Adolescent Literacy, 2017. http://www.adlit.org/strategies/19803/.

- - - "The SQ3R Reading Method." Study Guides and Strategies, 2017. https://www.studygs.net/texred2.htm.

Rike Marjulisa. "Pemahaman Konsep." Scribd, 2011. https://id.scribd.com/doc/67839324/Pemahaman-Konsep.

Slameto. Belajar Dan Faktor-Faktor Yang Mempengaruhinya. Jakarta: Rineka Cipta, 2013. https://search.mysearch.com/web?apn_uid=281A0B2C-51C9-43E78BA9-ED7C16DF675C\&b=ttb\&doi=2019-06-02\&gct=tab\&guid=281A0B2C51C9-43E7-8BA9ED7C16DF675C\&n=785869f0\&p2=\%5ECTP\%5Eprs001\%5EB2BMS\%5Eid\&si $=0 \mathrm{hca} 34 \mathrm{ee} 000021077301351$ B6145CB07EBF930FF6B57BA41870954a------.

Studio Belajar. "Besaran Pokok Dan Besaran Turunan - Pengertian, Contoh, \&amp; Dimensi." $\quad$ Studi 2015. https://www.studiobelajar.com/besaran-pokok-dan-besaran-turunan/.

Tanpa Nama. "PENGERTIAN PEMAHAMAN KONSEP." Berbagi Ilmu, 2016. https://www.rijal09.com/2016/04/pengertian-pemahaman-konsep.html. 